\title{
A future agenda for environmental restorative justice?
}

\author{
Miranda Forsyth, Deborah Cleland, Felicity Tepper, Deborah Hollingworth,
} Milena Soares, Alistair Nairn and Cathy Wilkinson*

\begin{abstract}
The challenges of developing meaningful environmental regulation to protect communities and the environment have never been greater. Environmental regulators are regularly criticised for failing to act hard and consistently, in turn leading to demands for harsher punishments and more rigorous enforcement. Whilst acknowledging the need for strong enforcement to address wantonly destructive practices threatening communities and ecosystems, we argue that restorative approaches have an important role. This article explores a future agenda for environmental restorative justice through (1) situating it within existing scholarly and practice-based environmental regulation traditions; (2) identifying key elements and (3) raising particular theoretical and practical challenges. Overall, our vision for environmental restorative justice is that its practices can permeate the entire regulatory spectrum, going far beyond restorative justice conferences within enforcement proceedings. We see it as a shared and inclusive vision that seeks to integrate, hybridise and build broader ownership for environmental restorative justice throughout existing regulatory practices and institutions, rather than creating parallel structures or paradigms.
\end{abstract}

Keywords: restorative justice, restorative practice, environmental justice, environmental regulation.

* Miranda Forsyth is Associate Professor at the School of Regulation and Governance in the College of Asia and Pacific in the Australian National University, Australia. Deborah Cleland is a Postdoctoral Fellow at the School of Regulation and Governance in the College of Asia and Pacific in the Australian National University, Australia. Felicity Tepper is a Senior Research Officer at the School of Regulation and Governance in the College of Asia and Pacific in the Australian National University, Australia. Deborah Hollingworth is a Principal Solicitor at the Environment Protection Authority Victoria, Australia. Milena Soares is a public servant at the Técnica de Desenvolvimento e Administração,Brazil. Alistair Nairn is Senior Engagement Advisor at the Environment Protection Authority Victoria, Australia. Cathy Wilkinson is Professor of Practice at Monash Sustainable Development, Australia.

Contact author: miranda.forsyth@anu.edu.au. 
Miranda Forsyth, Deborah Cleland, Felicity Tepper, Deborah Hollingworth, Milena Soares, Alistair Nairn and Cathy Wilkinson

\section{Introduction}

Climate change and predatory capitalism, amongst other factors, make environmental regulation today more challenging than ever before. Environmentally destructive practices continue to disproportionately affect the poor and disenfranchised as well as more-than-human spaces and lives. Faced with such challenges, environmental regulators ${ }^{1}$ are commonly viewed as 'toothless tigers' without sufficient power or resources. The urgent question arises: how can regulatory performance in this area be improved? We take a broad approach to the meaning of regulation, seeing it as that large subset of governance intentionally steering the flow of events (Black, 2001). This may involve rules and enforcement notices, but also involves measures such as influencing and educating. Stronger sanctions and better enforcement undoubtedly form part of the response, as do more imaginative campaigns for planetary stewardship of the environment, efforts to criminalise ecosystem destruction and initiatives to acknowledge the rights of nature.

Here, we suggest that restorative justice is also a key part of the regulatory mix. It creates an opportunity for existing regulatory traditions to better repair and correct harmful practices and prevent future environmental damage. We use the term 'environmental restorative justice' to indicate both how an environmental sensibility can contribute to restorative justice - particularly by embedding recognition of the interconnectedness of human and ecological relationships - and how restorative justice might apply in the context of environmental harm. The latter dimension is the key focus of this article. We avoided the term 'restorative environmental justice' as it implies making environmental justice, which is a discrete and distinct field of study and activism, restorative. Instead, we chose 'environmental restorative justice' to reflect our focus on all the ways in which restorative justice can play a role in environmental protection, restoration and care. We also see it as opening questions about what happens to restorative justice when it is infused with an environmental sensibility.

The past decade has produced noteworthy examples worldwide of both courts and regulators tying restorative justice to environmental regulation. For example, specialist environment courts in both Australia and New Zealand have experimented with using restorative justice conferences and sentencing. ${ }^{2} \mathrm{New}$ legislative approaches to environmental regulation such as Victoria's Environment Protection (Amendment) Act 2018 identify restorative justice as being important enough for inclusion alongside other enforcement options (see also Hamilton,

1 'Environmental regulators' refers to the administrative authorities invested with powers to inspect, invigilate and apply administrative penalties in the case of ecological/environmental harm.

2 Garrett v. Williams (2007) 151 LGERA 92, Chief Executive, Office of Environment and Heritage $v$. Clarence Valley Council [2018] NSWLEC 205 and New Zealand judges, facilitators and prosecutors have been supportive of environmental restorative justice (Al-Alosi \& Hamilton, 2019). 
this issue). ${ }^{3}$ In South Africa, pilot restorative justice projects addressing poaching are underway (Dore, 2019; see also Hübschle et al., this issue) and in early 2020, upon releasing its Environmental Justice White Paper, the chief justice of the Chinese Supreme Court announced: 'We should adhere to the idea of restorative justice, contextualise the needs of environmental restoration, and resort to plural approaches to healing the environment' (SPC, 2020: 1).

We seek to extend dialogue and debate about what an agenda for environmental restorative justice may take, in order to maximise its impact. Critically for us, environmental restorative justice is not just about adding new processes to supplement or replace current sanctioning processes. Rather, we seek ways to hybridise or integrate restorative justice more holistically into daily regulatory environmental practice, such that it permeates the entire regulatory spectrum. In developing this agenda, we have been motivated by three scholarly imperatives.

The first is to understand the existing shape of the environmental regulatory landscape, to ensure that environmental restorative justice is not viewed as a noisy interloper, but rather as a valued fresh approach that respects, and builds upon, the histories of success and failure experienced in the field. Decades of experienced and well-established voices have pursued the environmental protection agenda and environmental restorative justice needs to be understood within, and to find an appropriate niche alongside, existing initiatives for addressing environmental harms and inequalities.

Second, environmental restorative justice as philosophy, practice and principles should be legible and accessible to diverse environmental champions. This is especially important in contexts where restorative justice concepts and values, such as dialogue and participation, are already familiar; otherwise, those working in such contexts might struggle to see what is new about environmental restorative justice, or what more it offers.

Third is to acknowledge that environmental regulation raises specific conceptual challenges that are not present, or that manifest differently, in other domains where restorative justice has been used. We identify the following questions as important for future debate and theorising: Who are the victims of environmental harm? Who should have a voice in restorative processes and what process should be followed to decide this? What degree of offender acknowledgement of responsibility should be a prerequisite? What approaches are best, given that environmental offences are typically perpetrated by corporate entities? Who can speak on behalf of future or past generations and the more-

3 Several provisions support the integration of restorative outcomes. For example, at the conclusion of civil or criminal proceedings for an offence or contravention, the court may receive 'impact statements' from those affected, which can be considered in determining the outcome of the case. It is an option for the court to make a restorative project order requiring either the offender or a third party to undertake a project that enhances the environment, even if unrelated to the contravention (Section 332). Additionally, it establishes a restorative project account to fund such projects. The court may also adjourn proceedings and institute a restorative justice process (Section 336), after which the court may take into account the outcome of that process for its final determination. 
than-human ${ }^{4}$ (animals, plants, rivers, places, ecosystems, etc.)? How is harm measured, and what account can be made of future harm? Can irreversible environmental degradation be healed, and if so, how? Can restorative justice simultaneously safeguard communities and the environment? Each question deserves further detailed scholarship and practical exploration.

The first part of this article addresses the first of these scholarly imperatives through an overview of five distinct approaches or traditions within environmental regulation scholarship that have an a priori alignment with the core restorative justice values of participation, dialogue and partnership. We argue that whilst good reasons often exist for embracing a broad and loose tradition of restorative justice (Gavrielides, 2008), in the particular context of environmental regulation, with its long tradition of restorative values, it is beneficial to be more specific about what environmental restorative justice constitutes. The second part of this article therefore identifies five fundamental attributes of environmental restorative justice that we argue distinguish it from the five environmental approaches highlighted in this article. So, environmental restorative justice can be characterised as:

1 Fundamentally oriented towards healing, often of multiple harms, including relational and physical harm to humans/more-than-humans, inclusive of nature;

2 Based on requiring direct (not delegated) participation of those with power to take responsibility and make changes, and those who have suffered harm (inclusive of more-than-humans);

3 Based on storytelling and dialogue;

4 Dependent on identifiable harm, identifiable victims and identifiable individuals, groups or institutions who take responsibility for harm; and

5 Geared towards ensuring accountability of those who have created harm to those who have suffered harm, to achieve relational justice.

\section{Environmental regulation scholarship and environmental restorative justice: overlaps, contradictions and possibilities}

Here we synthesise five lineages or intellectual traditions in environmental regulation scholarship salient to environmental restorative justice. These approaches are: 1) distributed environmental management, 2) participatory conservation, 3) environmental justice, 4) social licence to operate and 5) green criminology. Emerging from varied social, ecological and economic contexts and pressures over the last five decades, each lineage has found a different disciplinary home and has focused on different actors as the protagonists of justice work. Acknowledging that each lineage contains depths, variance, contradictions and overlaps, we highlight the key ideas they represent and their

4 We use the term 'more-than-human' rather than non-human to signify a positionality actively aiming to be non-anthropocentric. 
restorative impulses, and draw forth the lessons they provide for developing environmental restorative justice.

\subsection{Distributed environmental management}

Distributed environmental management is our descriptor for the practice and philosophy of decentring the state's role in environmental regulatory control through collaborative regulatory mechanisms involving diverse actors. It emerged as corporations pushed back against rigid 'command and control' regulation that dominated early environmental regulation. Centralised, top-down regulation proved inadequate to deal with the proliferation and diffusion of pollution sources, types and scales of development activity, especially given the limited funding received by environmental regulators. Governments and academics alike have promoted a more flexible, risk-based and collaborative regulatory approach based on cost, efficiencies and efficacy (Steinebach, 2019). Various evolving umbrella conceptualisations have been proposed, including management-based regulation and new environmental governance (Gunningham \& Holley, 2016). The central link for each of these collaborative regulatory mechanisms is that the desired environmental outcome (e.g. limiting pollution, noise or odour) may be set by the government, but the pathway to achieving the goal is decided outside of the government, for example, through voluntary, third-party and/or marketbased instruments.

Expansion of the regulatory relationship from 'bipartite' (state/company) to 'tripartite' (state/company/community, the latter mainly represented through civil society organisations) is central to distributed environmental management. Based on cooperation and dialogue, the state negotiates its role amongst multiple actors, expanding and diffusing responsibility and accountability for environmental protection throughout different sectors of society, across time and space.

Three related elements of distributed environmental management overlap with central restorative justice values: direct participation, distributed accountability and responsive flexibility. Expanding the regulatory relationship to include 'communities' through direct participation is in part exactly what restorative justice aims to achieve. In turn, this participation distributes accountability, as offenders must answer not only to the state, as in criminal processes, but also to the wider community 'harmed' by their actions. Similarly, the responsive flexibility allowing third parties (e.g. civil society organisations and businesses) to devise the best way to meet environmental standards, aligns with a restorative justice approach of supporting all impacted by harm to participate in decisions about how to heal the harm. In contrast, distributed environmental management has no specific direct focus on healing - the greater emphasis on macro-policy regimes means that environmental harm (e.g. illness and death of humans/more-than-humans) is rarely dealt with explicitly, even if normatively desired.

Whilst encouraging innovation and tailored responses to environmental problems has resulted in some tangible improvements in responsiveness, many collaborative initiatives have required strong regulatory guidance and 
enforcement mechanisms to be effective. Without such safeguards, partnerships have frequently been short-lived, environmental improvements uncertain or absent and key 'offenders' have failed to participate (Gunningham \& Holley, 2016). When environmental outcomes are unclear and offending continues, there are often accusations and evidence of regulatory capture, ${ }^{5}$ in turn resulting in a breakdown of trust in decentralised and discretionary regulatory mechanisms. Thus, experience over past decades suggests that strong state-supported frameworks are critical to the effectiveness of collaborative processes (Steinebach, 2019).

Further, mechanisms that rely on community groups and organisations for accountability and enforcement are viewed increasingly warily by communities exhausted by constant claims on their time and attention, whilst they battle overly bureaucratic processes and inadequate, short-term funding arrangements (Holley, 2009). Similarly, restorative processes can place an additional burden on affected communities, who may perceive it as being a mechanism of 'risk-shifting' by the state onto other actors.

The precautionary lesson for environmental restorative justice is that it may be necessary to structure restorative responses inside stricter regulatory processes to ensure genuine healing of relationships and the natural environment. Strong accountability is essential to ensure sustained behavioural change and commitment from offenders, and to earn the trust of community and activist groups who are understandably reluctant to support processes that are perceived as being 'soft'. In practice, this may mean using restorative processes parallel to, rather than instead of, traditional prosecutions, as in the cases discussed by Hamilton (this issue). Overall, experiences of distributed environmental management over several decades suggest that environmental restorative justice initiatives require reliable, increased resourcing of nongovernment groups to ensure willing and effective participation, judicious selection of restorative justice candidates and strong regulatory oversight.

\subsection{Participatory conservation}

Participatory conservation approaches cover diverse frameworks of natural resource management that seek to involve stakeholders in environmental governance (Dovers, 1998). Their focus is biodiversity conservation, national park management and common pool resource management - the 'green' side of environmental regulation. Emerging in the 1970s, the 'participatory turn' recognised that consultation and inclusion was 'the politically most feasible and socially most just form of conservation possible' (Nygren, 2004: 189). Since much of the activity is voluntary, regional and community-based (Richardson, 2015), the state lacks the reach or power it has in other domains. This values-based orientation distinguishes the approach from distributed environmental management, which tends to justify participation on efficiency and technocratic grounds.

5 Regulatory capture refers to a situation where the regulation in question has a bias in favour of the regulated industry or other political actors, to the detriment of public interest. 
Researchers - particularly environmental social scientists, ecologists and conservation biologists - have played an active and central role in designing, developing and documenting participatory projects and programmes in this domain (Brown, Harris \& Russell, 2010). This has led to a vast body of related scholarship conceptualising and theorising how different sectors and disciplines can work and learn together (Polk, 2014). Arguably, whilst participatory conservation does not use terms such as 'offenders' and 'victims', but rather 'interest groups' and 'stakeholders', its long, broad experience in bringing together diverse groups to negotiate agreements and future plans means it can offer valuable experience to environmental restorative justice.

Perhaps the most important lesson from participatory conservation is the rich body of literature criticising 'participation' for functioning as placebo rather than panacea. Scholars have noted that many face-to-face gatherings branded as 'participatory' can result in entrenching conflict, exclusion and silencing of particular social groups, and promoting false consensus that disintegrates once back in the 'real world' (Cooke \& Kothari, 2001). Restorative justice has long emphasised the need for skilled facilitators, significant investments in preparatory work and 'buy-in' from all key players. However, participatory conservation warns that where deep mistrust and asymmetrical power relationships exist, skill and time will not always be enough to guarantee acceptable outcomes for community members (Agarwal, 2001). It may be that environmental restorative justice's emphasis on healing of self and multiple sets of relationships can provide a useful new approach to overcoming such participatory reluctance and disenchantment. Finally, participatory conservation literature points to the importance of incorporating a broader awareness and appreciation of cultural contexts and communication strategies and effectively navigating power differentials. These are all likely to be critical for upholding environmental restorative justice's shared values of respect, accountability and responsibility.

\subsection{Environmental justice}

Environmental justice as a normative ideal is achieved when communities have the right and capacity to participate meaningfully in environmental decisions affecting them, and when no individual or group is disproportionately impacted by the outcomes of such decisions, including future generations (Jessup, 2017; Lukasiewicz, 2016). Environmental justice scholars analyse resource conflicts, pollution distribution and decision-making through this lens, whilst activists aim to create an environmentally just world (Bullard, 1994; Holifield, Chakraborty \& Walker, 2017).

As a consequence of examining unjust outcomes of administrative and legal decision-making, environmental justice scholarship has historically focused on community activism and failures of regulatory systems to protect and give voice to marginalised communities and social groups - particularly, Indigenous groups and ethnic minorities (Taylor, 2000). Environmental justice movements across the world are known for sometimes rejecting the formal justice system entirely, often using protest, including demonstrations and blockades. Herein lies a key 
difference from mainstream restorative justice, with its state-sponsored operationalisation from within regulatory systems, for example, in schools and criminal justice, albeit occupying a marginalised position.

In comparison to restorative justice, environmental justice places greater emphasis on the structural causes and consequences of uneven distribution of harms across time, space and demographics. This is partly due to the differing scale of focus: restorative justice typically involves an individual or communityfocused intervention after a particular harm (although its increasing role in largescale peacebuilding efforts is changing this), whereas environmental justice tends to be a community-focused response to a problem perceived as structural, systematic and repeated. Here, the harm is not considered one-off or mutually constituted. Rather, it results both from exclusion, poverty and disempowerment of communities and particular groups, and from impunity, wealth and privilege of state and corporate actors.

Notwithstanding this difference in scale and focus, both restorative justice and environmental justice arose from a deep dissatisfaction with mainstream policy and judicial decision-making. Both are characterised by special attention to context - to the unique configurations of communities, time and place that have led to harm and that can help in healing and preventing future harm. Like restorative justice, environmental justice centres inclusion and participation to challenge the assumptions behind the 'business as usual' processes of courts and regulatory activities, and both utilise a 'justice' framing.

\subsection{Social licence to operate}

The social licence to operate is a public policy concept that involves developing trust in and the legitimacy of corporate activity from the community's or stakeholders' perspective. Conceptualised in 1997, it centred on responding to social risks impacting the mining industry by developing 'an ongoing positive relationship with local communities and their allies' (Cooney, 2017: 199) and has since expanded to other industries. ${ }^{6}$ The social licence to operate is unwritten, informal and unregulated (Duncan, Graham \& McManus, 2018). Unlike mandatory statutory licences, the 'licence' is neither legal nor regulatory in nature but provides a metaphor for earning permission from the community within which the project is based - a type of 'community licence' (Cooney, 2017; Hampton \& Teh-White, 2019). Another aspect is the community's ability to enforce the social licence informally, for example, through lobbying, activism or boycotts, thereby threatening potential loss of it where the company fails to conform to community expectations, including meeting its legal licences (Gunningham, Kagan \& Thornton, 2004; Hampton \& Teh-White, 2019). A company that both gains and maintains a social licence tends to be transparent, has proactive stakeholder engagement (listening to and heeding the community,

6 Principally the licence was extended to resource industries like forestry, paper pulp and fishing (Edwards et al., 2019; Gunningham et al., 2004), and recently further applied to racing business and wildlife management (Duncan et al., 2018; Hampton \& Teh-White, 2019). 
including opponents) and leads industry with compliance (even going 'beyond compliance').

As with restorative justice, the social licence to operate is about relational justice in seeking to improve relationships or 'contact quality' (Edwards et al., 2019: 7). Other shared restorative values include emphasising dialogue, building trust and accountability, multidimensional respect and contextual flexibility. Importantly, the social licence is characterised as a two-way process: the company does not control it but rather has to earn it by listening, responding, and making and keeping promises over the project's duration. The independence of third parties, who can verify claims and monitor promises, is critical.

Social licence practices and associated developing scholarship potentially have important lessons to offer environmental restorative justice. In particular, the ongoing nature of operationalising the licence and its potential for removal at any time forces the company to remain aware of social values, attitudes and needs, not just at the time of any conference, court or regulatory decision, but for the whole duration of the project/activities. It provides a useful potential discursive strategy in the context of environmental restorative justice to highlight the need for ongoing relationship-building and maintenance. Practices developed around communication, particularly reporting back to communities, are also valuable - for a social licence to work, the company's story needs to be heard by the community: 'It is not enough for an industry to change its practices ... if the community is unaware of the fact' (Hampton \& Teh-White, 2019: 17).

Failures with both conceptualising and executing the social licence contain valuable lessons for environmental restorative justice. For instance, where a company cares little about reputational loss (due to having no brand to lose), or where it prioritises shareholder/corporate strategies, the licence is unlikely to gain a foothold (Gunningham et al., 2004). Moreover, if the licence is ambiguous, its application can opportunistically veer into corporate spin or lead the company to share only positive or confusing information (Edwards et al., 2019). There is a risk too of overlooking non-visible environmental harms (Lester, 2016). From the community's side, a 'company town' may defend the company or lack the 'power to resist corporate activity' (Demuijnck \& Fasterling, 2016: 681), whilst if the company chooses to narrowly define 'community', it might selectively determine who is worth listening to, demonising those sectors of the community it feels threatened by as being 'extremist', 'irrelevant' or 'irrational' (Edwards et al., 2019; Gunningham et al., 2004).In return, restorative justice has much to offer social licence scholarship and practice. Restorative justice can offer a neutral, safe environment in which to have structured discussions about uncertain aspects of the social licence, which may be especially beneficial to alleviating ambiguity over what and who is contributing to it. In practice, this may involve setting up formal participatory bodies to ensure ongoing dialogue between regulators, companies and the local community. Restorative conferencing may also present an opportunity to regain a stalled or even lost social licence through clarifying prevailing community values or wishes and realigning company practices with these, including developing measures addressing responsible future corporate behaviour (Wijdekop, 2019b). 
Miranda Forsyth, Deborah Cleland, Felicity Tepper, Deborah Hollingworth, Milena Soares, Alistair Nairn and Cathy Wilkinson

\subsection{Green criminology}

Green criminology is concerned with environmental harm that affects human and more-than-human life, ecosystems and the biosphere (Brisman \& South, 2019). The 'green' criminological perspective is critical and harm-based, focusing on how environmental harm is often caused by lawful (as well as unlawful) statecorporate behaviour. Consequently, it highlights structural causes and challenges statutory definitions of crime (White, 2017; see also Varona, this issue).

First advanced in the 1990s as a 'unifying theme' and 'rallying point' to enhance the cogency of previous studies on 'green issues' (e.g. toxic waste disposal, environmental racism, corporate negligence and victimising future generations), green criminology is built upon diverse scholarly and activist traditions, and is underpinned by various eco-philosophical orientations on human-nature relationships (anthropocentric, bio-centric or eco-centric). It seeks to frame new types of environmental crimes, harm and victims (Nurse, 2015).

Advancing a broad concept of eco-justice that embraces diverse worldviews, green criminology stretches victimisation to include humans, non-humans ${ }^{7}$ and ecosystems (Brisman \& South, 2019). The anthropocentric perspective emphasises human rights and distributional (including intergenerational) equity, the bio-centric orientation focuses on animal rights and conservation of species, whilst the eco-centric perspective focuses on rights of nature and conservation of places (ecosystems and biosphere) (Brisman \& South, 2019; White, 2018). Recent worldwide legal initiatives have acknowledged the rights of nature ('Earth jurisprudence'), meaning that natural elements have legal personhood and standing in court. ${ }^{8}$ In practice, if nature is harmed, the right to restoration cannot be transacted to benefit individuals' self-interests (Clark, Emmanouil, Page \& Pelizzo, 2019).

Challenges that green criminology has faced are likely to beset environmental restorative justice too. First is how to meet the conflicting justice needs of divergent groups of victims, such as satisfying human nutritional demands through animal slaughtering (human rights versus animal rights). Ecological justice can be at odds with social justice and human rights: Davies' (2014) case study of Rio Tinto Alcan's smelter closure in England shows how a successful global green agenda (reducing greenhouse gas emissions) unintentionally victimised local communities, causing unemployment and exacerbating poverty.

7 As noted earlier, we use the term 'more-than-human' but acknowledge the usage of 'non-human' within green criminology.

8 For example: In 2008, Ecuador assigned constitutional rights to the Pachamama (Nature) of existence, maintenance and regeneration, invokable by any natural or legal person in court. Within eight years, ten (out of thirteen) cases were decided in favour of Pachamama (Clark et al., 2019). In 2017, New Zealand approved The Te Awa Tupua Act to confer legal personhood to the Whanganui River, creating a governance structure to operationalise representation of the river (Clark et al., 2019). In Australia, the movement is consubstantiated in the Yarra River Protection (Wilip-gin Birrarung murron) Act 2017 of the state of Victoria, acknowledging the river as a single living and integrated natural entity for protection (Clark et al., 2019). In 2016, The Atrato River case, in Colombia, recognised the legal rights of the River Atrato to protection and the joint appointment of the Indigenous people and the government as custodians of the river (http:// files.harmonywithnatureun.org/uploads/upload838.pdf). 
A second challenge is how to access the voices of more-than-human animals, plants and ecosystems that must by necessity be represented through humans. Within the green criminology framework, these voices are represented through scientific evidence (Lynch \& Stretesky, 2011). This is unsurprising given that knowledge and expert authority is still centred in the Global North, echoing colonial structures that disenfranchise other sources of knowledge (Goyes, Sollund \& South, 2019). A future agenda for environmental restorative justice is to consider what other possibilities exist.

A third challenge is the relative impunity for crimes of the 'powerful', given structural factors such as the 'treadmill of production' and a growth-driven society (Stretesky, Lynch \& Long, 2014). Green criminologists argue that profitdriven corporations traditionally account for regulatory sanctions/fines as a cost of doing business, encouraging recidivism. Some further argue that only substantial financial penalties act as deterrents, raising doubts about the potential of a restorative approach (White, 2017). Moreover, transnational environmental crimes add a level of complexity that challenges the effectiveness of deterrence, such as global-scale illegal wildlife trade by transnational criminal organisations (Arroyo-Quiroz \& Wyatt, 2019).

\subsection{Wayfinding from the five approaches}

These five approaches reveal many threads in the existing literature and praxis, upon which the new agenda of environmental restorative justice can be built. Table 1 gathers these together in categories for heuristic purposes, noting, however, that regulatory practice often straddles categories.

Our brief tour highlights both tensions and oppositions within existing environmental scholarship and praxis that may contain relevant lessons for environmental restorative justice. Questions of more-than-human victims and community-as-victim expand and challenge traditional conceptions of victimhood. From both green criminology and environmental justice perspectives, the state is often seen as complicit in, or even actively contributing to, environmental harm. These factors blur the role of, and boundaries between, victim, offender, community, regulator and facilitator. Theory and experience from social licence to operate and participatory conservation point to the interrelationships between place-based relationships, power and trust in creating accountability, responsibility and inclusion when attempting to address harmful practices. Similarly, lessons from the regulatory practices of distributed environmental management indicate that relational approaches alone are unlikely to achieve more inclusive environmental regulation. This insight resonates with evidence from other domains that suggest a combination of restorative justice and court orders may be more effective than either pursued separately (Braithwaite, 2016). Strengthening the voices, control and access of marginalised groups both through and beyond state-sponsored programmes of restorative justice will be essential for effective environmental restorative justice. 


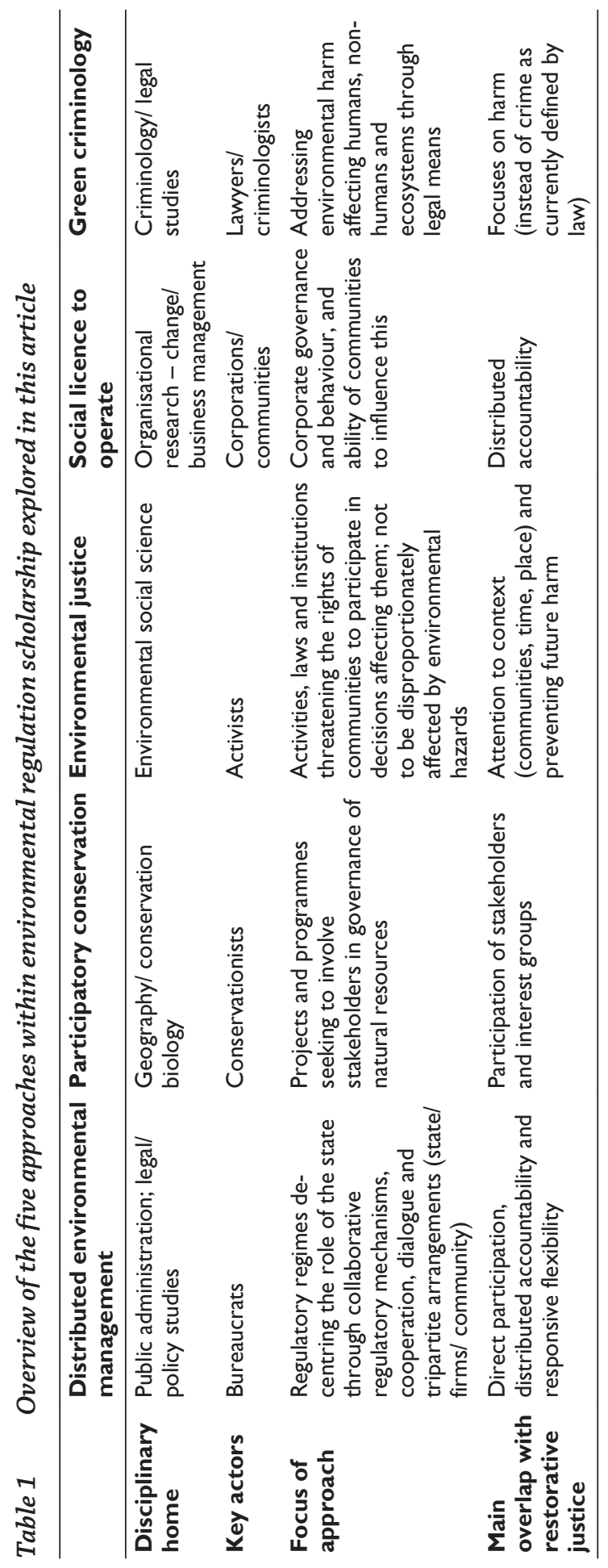


Figure 1 The elements of environmental restorative justice

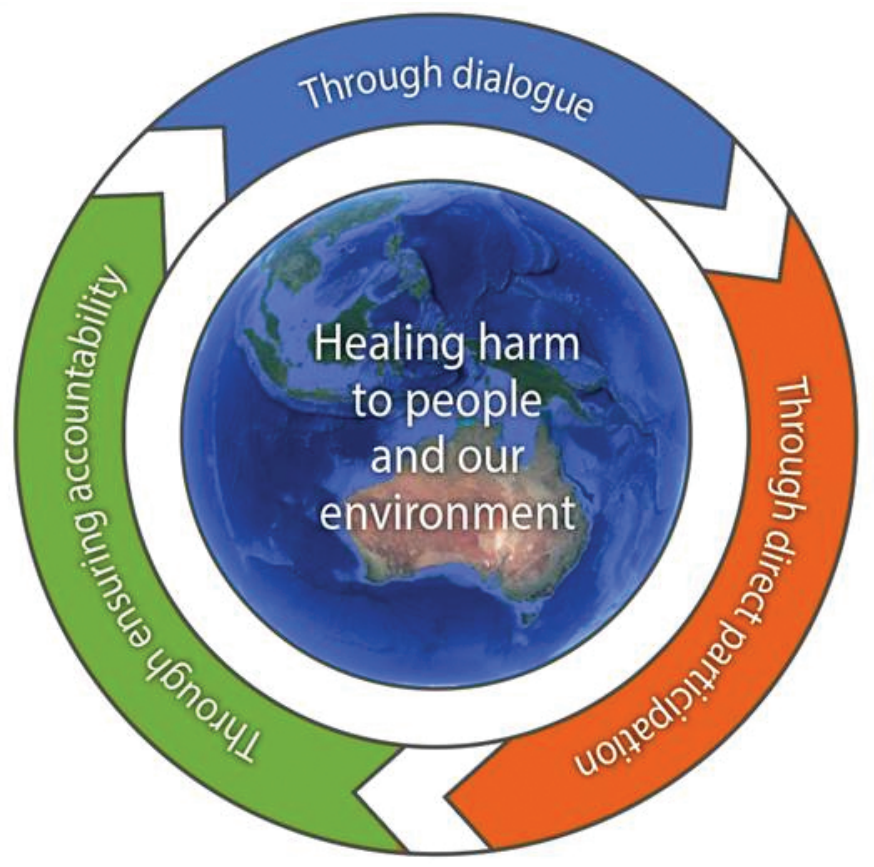

\section{Environmental restorative justice: five key attributes}

Our discussion above has revealed many key restorative values and principles already centrally integrated into existing environmental regulation and justice traditions. What does environmental restorative justice add to this landscape, and where might challenges emerge?

To date, those advocating greater engagement with restorative justice in the context of environmental regulation have tended to focus on the value of restorative justice conferences as a tool to be added to enforcement procedures (e.g. Hamilton \& Howard, 2020). However, our hypothesis is that just introducing restorative justice conferences to regulatory organisations to address specific incidents holds far less transformative potential than a cultural commitment to thinking restoratively at all stages of regulatory processes. Consequently, we need to be clear about what 'thinking restoratively' entails in the environmental context.

We now explore five attributes central to shaping environmental restorative justice: healing, participation, storytelling, categorising harm and accountability (depicted in Figure 1). This listing is exploratory and is neither hierarchical nor exhaustive. Further, we identify challenges likely to arise in applying these attributes to the environmental context, alongside possible ways forward suggested by the five intellectual traditions above. 


\subsection{Healing harm to people and our environment}

Environmental restorative justice is fundamentally oriented towards healing and restoration - of communities, of relationships, of institutions and of ecosystems damaged by human action or inaction (see Braithwaite, 2002; Zehr, 2014). In this context, restoration does not refer to making whole or perfect, but rather to finding relational peace, or improved conditions of healed harms, under which to continue coexisting. Healing involves creating the conditions for repairing wounds whilst accepting that scar tissue, changed aesthetics and reduced/altered ecosystem functions may be ongoing consequences of past actions. Healing is dynamic, not static.

Although healing and restoration certainly encompass emotional and relational healing, physical healing is easiest to explain. Repair of a damaged environment could include replanting, rehabilitating, rewilding or detoxifying none of which would imply a return to a 'pristine' state - whatever that might mean in a world of constant, non-linear change. Rather, environmental restorative justice could mean finding ways of restoring biodiversity, ecosystem health, access to or safety of places that have been damaged and restoring or revivifying care of place, taking into account the particular histories, lore, values, inhabitants and potentialities of each site. Regard to Indigenous cultural values and heritage is a centrally important component of healing.

Relational and emotional healing is central to all restorative justice. As Pemberton and Aarten (2018: 549) explain, victimhood 'ruptures' life stories and 'shatters assumptions' about our identities, and our relationships with place and others. A fundamental part of healing these ruptures and shattered assumptions is to find a way of 're-storying' the experience of being harmed, to enable victims to integrate and understand both what happened and what needs to happen to 'put things right'. Environmental restorative justice offers both the time and space needed for victims and offenders alike to reconstruct their relationships towards themselves and each other.

\subsection{Direct participation of perpetrators/enablers of and those impacted by environmental harm}

Restorative justice requires direct participation by the individuals or corporate representatives who have caused harm or enabled it to occur. In this respect, it is unlike many forms of enforcement reliant on lawyers and other representatives and advocates to act on behalf of the injured party. As theorised in various ways, most notably through Rossner's (2013) work on the micro-interactions that occur during restorative justice processes, restorative justice 'works' in part through emotional involvement of the parties, both with themselves and with each other (also Bolitho, 2017).

Through dialogue and personal interactions between those who have been harmed and those responsible for allowing harm to happen, environmental restorative justice can create empathy amongst stakeholders. It can facilitate direct and mutual learning, not only about the harm's impact, but also the exact circumstances behind it, providing an opportunity to identify and address 
misunderstandings. Going beyond questions of 'what law has been broken?' or 'what regulatory procedures were not followed?', environmental restorative justice heads directly to emotionally engaging questions of how a community subjectively experienced harm. David Moore, a long-time practitioner of restorative justice, explains that it is through collective re-narration of events that emotional transformation of all participants of a restorative justice process can occur (Moore, 2019).

Direct participation means ensuring that the affected community gets to talk directly to people who have the positional power to effect change in corporate or regulatory structures, attitudes and processes, not just an offer to 'take it back to the boss'. Whilst potentially highly challenging to existing corporate culture, this enables real traction and leverage, gaining not only meaningful interactions but actionable change because those who control the resources have said 'yes'. This ability of environmental restorative justice to bring together leaders who have the agency to effect change with community members brimful of ideas on what types of responsiveness would satisfy their need for a cleaner, safer and cared-for local environment, benefits all parties involved.

Direct involvement of regulators in environmental restorative justice also provides an ideal opportunity to learn about the on-the-ground impacts of their institution's practices. Ideally, regulator involvement can provide accountability for poor past practices, increase responsiveness to the public and enable learning about how to better address the impacts of environmental harm on human beings and the ecosystems. In this way, the theme of state complicity for environmental damage, critiqued by green criminology and environmental justice, can be mobilised and explored through environmental restorative justice. Institutional betrayal, whereby communities and individuals feel forsaken by the very institutions meant to protect them, is of real concern in the environmental context. Restorative justice provides regulators with a way to engage with institutional betrayal that allows demonstration of institutional courage (Smith \& Freyd, 2014); the narrative structure of a restorative conference allows the typically siloed perspectives of regulatory participants to be unpacked and revealed, enabling cooperative, collaborative institutional learning.

\subsection{Storytelling and dialogue as conversational empowerment}

Restorative justice involves a structured, safe space that provides room for victims of harm to tell their stories, and for those who have caused or been responsible for harm to listen and respond. The simple act of talking and listening can be profoundly transformative. Few court hearings offer sufficient opportunity for victims to tell their story and be heard, particularly since court processes often reduce testimonies to written form, such as affidavits of evidence, and may rule as inadmissible the evidence which upsets people most. Consistent empirical evidence shows that victims report greater feelings of being 'heard' in restorative justice processes than in conventional justice processes (Braithwaite, 2016). Whereas dialogue can simply involve an exchange of facts, stories retell personal and collective experiences to establish important context and common ground, whilst also bridging and explaining disagreement in norms 
and understanding (Cleland \& Ocaya, 2018). Specifically, storytelling allows for the inclusion of perspectives that can otherwise go unheard and situates events in time and place. This is an important dimension of environmental restorative justice because of the need to make audible the voices of more-than-human victims. One possibility for giving environment a voice is to visit a place during a restorative process, and for those visiting to experience the story of that place through all of their senses.

As recognised in many of the environmental traditions above, dialogue and storytelling, and the settings in which these occur, are centrally important for restorative justice. Most commonly, restorative justice is structured around questions that involve participants reflecting on their feelings ("how did you feel then?') and expressing their own ideas about what contributed to the harm and what needs to be done to make things better (and by whom). Respectful listening and turn-taking, often in circular seating arrangements, heighten the sense of inclusivity. By contrast, common regulatory approaches focus on adversarial dialogue, emphasising direct or indirect determination of what rules were broken and by whom, with heightened attention to evidence-gathering, avoiding admissions and punishment.

Restorative justice storytelling and dialogue differs from the space allocated to dialogue in forums such as unstructured 'town-hall' meetings that characterise many attempts to garner community participation in the environmental context. In particular, restorative justice emphasises co-producing an account of harm, and focuses on achieving a form of justice 'that makes for a better tomorrow' (Froestad \& Shearing, 2007). At its best, it illuminates structural or systemic factors that resulted in the particular harm and its impacts, widening the circle of responsibility (and ideally, accountability [see Llewellyn, 2019]), as discussed below.

An important issue to address is determining how, and to whom, those who are tellers of stories in restorative processes are accountable. As noted by a reviewer of this article, the difference between stories told from the heart and 'spin' can be hard to differentiate even for members of the same groupings.

Our initial hypothesis is that environmental restorative justice would likely benefit most from utilising a mix of forums, with 'thicker' and 'thinner' forms of story-sharing being brought into play, dependent on context. Sometimes, conversationally driven agreements between a small affected group and regulators can be effective in the sense of 'thick' storytelling; and whilst town-hall meetings deliver 'thinner' participation and story-sharing, they do enable face-toface participation of hundreds of people, something not possible with 'thicker' storying. A contextually responsive mix of these 'thick and thin' restorative engagements would ensure conversational empowerment.

\subsection{Harm categories within environmental restorative justice}

Questions of harm, victim and those taking responsibility for harm (whether or not they have committed an 'offence') are particularly challenging in the environmental context, due to the multiple point sources of harm, entangled layers of causation exacerbated by climate change, questions surrounding harm to 
future generations and harm to more-than-humans. Degrees of responsibility vary enormously; harms are experienced in diverse and dispersed ways and often those causing harm also experience harm.

Our position, open for debate, is that currently, environmental restorative justice would benefit from using the categories of harm, victims (and voice) and those taking responsibility for harm, as anchor points. We refer to 'those taking responsibility for harm', rather than the more common term of 'offender', to signify that those taking responsibility for healing harm have diverse motivations, time frames and positionalities; it includes those morally and legally responsible for causing harm, and also those with different responsibilities and connections to it. Environmental restorative justice has value as a journey during which diverse actors inhabit the space to take active responsibility for healing harm. We also embrace the wisdom of ecological justice insights that centres recognition of the moral responsibilities towards different species and ecosystems at the same time as restoring human relationships.

We see focusing on an identifiable harm as a productive way to catalyse immediate, directed action and note that identifiable harm may include future harm. Indeed, conventional environmental regulation's risk-based and approvals focus is biased towards future events (Richardson, 2015), as evidenced by the relatively high resourcing of approvals and licensing as compared to compliance and enforcement. Through its ability to engage with complex problems from multiple angles, environmental restorative justice can foreground harms more likely to recur and thereby serve a preventative function. Restorative justice processes are well positioned to identify regulation and policy shortcomings, as resolving conflict and harm may hinge on the effectiveness or inability of regulatory/policy requirements to prevent harm. Harnessing such learnings and feeding them back into standards development, whether immediately or in the future, is the real challenge. The restorative focus of building stronger relationships can also serve a powerful preventative function, for example, through building networks of shared knowledge and advocates for the environment. Additionally, restorative justice often focuses on past harm and historical injustice, an understanding of which is crucial to achieving just futures (Golub, Mahoney \& Harlow, 2013). In this regard, both in relation to Indigenous lands and more broadly, any restorative approach needs to centralise acknowledgement of, and responsiveness to, previous injustice.

How the voice of the environment is represented and accounted for in restorative environmental justice requires critical inquiry. Voiceless victims, such as rivers, plants and animals, challenge the sense of connectedness sought to be reached during a restorative encounter because of the human ontological impossibility of knowing what it is like to be a river, plant or animal, potentially hindering the emergence of empathy towards more-than-human victims. Arguably, the 'problem is not their speaking but rather our failure to hear' (Besthorn, 2004: 42). Wijdekop (2019a) argues:

Recognizing the environment as a victim of environmental crime and representing it in the Restorative Justice process grants the Earth a voice, 
Miranda Forsyth, Deborah Cleland, Felicity Tepper, Deborah Hollingworth, Milena Soares, Alistair Nairn and Cathy Wilkinson

validity, and respect. [...] It contributes to transforming humanity's relationship with the Earth from one of exploitation towards a duty of care.

Whilst most conventional environmental legislative frameworks afford environmental protection, few attribute direct recognition to the environment as a legal entity able to prosecute its interests because more-than-human rights are invisible in current legal systems (Cullinan, 2017). However, as discussed above, activism and jurisprudence around the rights of nature are growing internationally (Cullinan, 2017). A live question for environmental restorative justice is whether taking a rights-based approach favours legalism instead of exploring the ongoing relationships between people and place and Indigenous approaches to recognising nature's voice.

One fruitful way to give the environment voice is through using humans with local knowledge and place attachment as proxies (Lowe, 2014). This may involve Traditional Owners or local community groups connected to particular places, as well as ecologists, historians and environmental organisations. For example, with the aid of the Internet of Things, information gathered from daily monitoring of environmental harm by citizen groups could be nurtured and supported in a transparent and collaborative way, to increase the potential for greater engagement of regulators with those closest to sites of environmental harm. ${ }^{9}$

Future generations constitute another important category of victim highlighted by, amongst others, environmental justice advocates. Emerging jurisprudence in some national courts recognises the rights of future generations to be represented in judicial proceedings. ${ }^{10}$ This recognition needs to be incorporated into environmental restorative justice.

A further question is how a heterogeneous community, particularly one containing interest groups at odds with each other, is represented. Environmental restorative justice must address how to develop reflective, deeplistening practices that ensure disempowered or quietened community members, such as migrants and Indigenous people, have their voices heard, and how to enable participation by large numbers of impacted people. Potentially, this is achievable by separating out the storytelling part of a conference addressing 'what happened', where all voices should be heard, from negotiating the agreement, where some leadership/champion-representative approach may be more successful. Additionally, environmental restorative justice can learn from environmental justice and participatory conservation about the need for an inbuilt attentiveness to the structural and procedural causes behind inequalities, exploitation and the power imbalances experienced by disadvantaged communities. Mechanisms such as corporate integrity agreements or enforceable

9 Environment Protection Authority Victoria has, for instance, a citizen science programme seeking ways to improve local engagement: https://ref.epa.vic.gov.au/our-work/programs/ citizen-science-program.

10 See, for example, the 1993 Philippines Supreme Court decision Oposa v. Factoran 224 SCRA 792; and the 2018 Colombian Supreme Court decision Future Generations v. Ministry of the Environment and Others (decision available at http://climatecasechart.com/non-us-case/futuregeneration-v-ministry-environment-others/?cn-reloaded=1). 
undertakings that mandate minimum standards of content and participation in restorative processes, may help to counter domination by the more powerful, when astutely enforced.

For our final suggested category, environmental restorative justice can widen the net of those taking responsibility for harm by raising awareness about structural and systemic factors that lead to environmental harm. Ideally, it can reach managers at the very top of the value chain, creating an awareness of the downstream harm their manufacturing/production or business strategies cause. This is critical in environmental regulation, especially given that certain industries are prone to re-offending or in cases where government regulation is sparse or misses emergent issues. Unlike in an adversarial system where the dispute's ambit is limited by strict rules of relevance, a restorative justice process can systematically widen the circle of accountability and responsibility for repair, requiring and making visible responses from those with the highest levels of institutional responsibility. Structural contrivances and shielded linkages with other organisations that may otherwise have remained invisible or immune to scrutiny can be made transparent through restorative dialogue, increasing awareness of corporate responsibilities. This gives rise to the possibility of restorative agreements addressing correction and repair of governance structures within the organisation that caused harm, and ideally signals the virtues of lifting standards across that industry overall.

\subsection{Accountability: achieving relational justice}

Accountability requires a willingness from those holding power (regulators, corporations, influential civil society groups, etc.) to accept responsibility for their actions, to explain and make transparent their decisions and to be responsive to affected people and communities (Koppell, 2005; Moore, Greiber \& Baig, 2010). In the restorative sense, accountability is not limited to legal breaches, be they civil or criminal, but widens accountability to the whole range of victims harmed, be they human individuals/groups or more-than-humans. Being held accountable for creating harm and for healing harm is central to environmental restorative justice.

Accountability from those holding power is a powerful concept - if adhered to. Yet, in most regulatory contexts today, third parties (e.g. the community, small businesses, proxies for more-than-humans) do not have anything approaching a veto power. Whilst often consulted to varying degrees in attempts to fulfil expectations of transparency and informing people, ultimately the final decision-making remains with regulators or courts, frequently without feedback to the community on why their views and needs were not prioritised. Often justified on the basis of achieving consistent decision-making (as if one-size-fitsall equates to fairness), such an exclusion fundamentally undermines the agency of the community or other third-party harmed. In contrast, accountability in the context of environmental restorative justice requires placing genuine power into the hands of those harmed, to reject, modify or co-design the proposed solution of those taking responsibility for harm. 
One lesson from the social licence to operate is that where self-regulation and voluntary commitments to engage the community and protect the environment fail, the 'licence' can be revoked by that community and its allies, through persuasive techniques such as protestor demands to enforce existing regulatory requirements. This response has limitations, for example, where community efforts are ineffective or a majority within a community negatively impacts vulnerable or disengaged members; or where corporate obstructionism exists, or governments fail to adequately engage a community. Thus, ongoing voluntary commitments need strongly forged relationships between industry and community to keep accountability at the forefront, something environmental restorative justice could foster.

\section{Conclusion}

This article identifies environmental restorative justice as a promising new branch of the restorative justice tree. It further proposes weaving practices of environmental restorative justice through a broader range of everyday environmental regulation activities. Sprouting from soil already tended to and fertilised by generations of Indigenous communities, community activists, creative judges, concerned lawyers, engaged bureaucrats, visionary corporations and committed activists, environmental restorative justice draws on a rich heritage of restorative values and actions from which to learn in developing in both practice and theory.

Mindful of these roots, we have also identified how environmental restorative justice contributes its own novel perspectives and possibilities for restoring and healing relationships towards and within the environment. Philosophically, environmental restorative justice includes, but goes beyond, providing a relational and emotionally intelligent means for doing justice in relation to environmental harm. At its most ambitious, we view it as driven by our first attribute, healing Earth systems and healing the relationship of humans with nature and with each other. Practically, it is about asking what taking responsibility really entails, which in part, our other four attributes of environmental restorative justice demonstrate: (1) direct (not delegated) participation of those with power to effect genuine change alongside those who have suffered harm; (2) making space for storytelling/dialogue and authentic listening; (3) identifying the harm, giving voice to all victims and identifying those who must take responsibility for harm and (4) being accountable both now and in the long term. More idealistically, we envisage taking responsibility as being something that expands as restorative processes, with their face-to-face encounters and deep engagement, nourish more complex understandings of our relationships with each other and our planet.

Our conceptualisation of environmental restorative justice seeks to forge a new vision in which humans pursue a harmonious, restorative relationship towards nature and with each other. Through providing a commonly shared language and set of principles, it can assist to bridge different scales, link personal 
and community experiences, strengthen divided communities, provide pathways to better stand up to corporate misdeeds or indifference and bring together corporations, regulators and the not-for-profit sector. Environmental restorative justice can be used to amplify the voices of impacted individuals and communities to encourage and require those responsible for environmental harm to be accountable and to effect genuine healing for communities and nature. We dedicate opening up this dialogue and debate to all champions of the environment - in our schools, institutions, corporations and Indigenous communities, environmental stewards, citizen scientists, friends of creeks, keepers of waterways, multitudinous community groups and, of course, the regulators of our industries.

\section{References}

Agarwal, B. (2001). Participatory exclusions, community forestry, and gender: an analysis for South Asia and a conceptual framework. World Development, 29, 1623-1648. doi: 10.1016/S0305-750X(01)00066-3.

Al-Alosi, H. \& Hamilton, M. (2019). Australians should give victims a voice in tackling environmental crimes. The Conversation. Retrieved from https://theconversation.com/ australia-should-give-victims-a-voice-in-tackling-environmental-crimes-115711 (last accessed 04 August 2020).

Arroyo-Quiroz, I. \& Wyatt, T. (2019). Wildlife trafficking between the European Union and Mexico. International Journal for Crime, Justice and Social Democracy, 8(3), 23-37. doi: 10.5204/ijcjsd.v8i3.1243.

Besthorn, F.H. (2004). Restorative justice and environmental restoration - twin pillars of a just global environmental policy: hearing the voice of the victim. Journal of Societal and Social Policy, 3(2), 33-48.

Black, J. (2001). Decentring regulation: the role of regulation and self-regulation in a 'postregulatory' world. Current Legal Problems, 54, 103-146. doi: 10.1093/clp/54.1.103.

Braithwaite, J. (2002). Restorative justice and responsive regulation. Oxford: Oxford University Press.

Braithwaite, J. (2016). Restorative justice and responsive regulation: the question of evidence. RegNet Working Paper No. 51, School of Regulation and Global Governance (RegNet). Retrieved from http://johnbraithwaite.com/wp-content/uploads/2016/11/figuresJBdotcom-SSRN_2016_BraithwaiteJ-revised-51.pdf (last accessed 04 August 2020).

Brisman, A. \& South, N. (2019). Green criminology and environmental crimes and harms. Sociology Compass, 13, 1-12. doi: 10.1111/soc4.12650.

Bolitho, J. (2017). Inside the restorative justice black box: the role of memory reconsolidation in transforming the emotional impact of violent crime on victims. International Review of Victimology, 23, 233-255. doi: 10.1177/0269758017714549.

Brown, V.A., Harris, J. \& Russell, J. (eds.) (2010). Tackling wicked problems through the transdisciplinary imagination. London: Earthscan.

Bullard, R.D. (1994). Dumping in Dixie: race, class, and environmental quality. Boulder: Westview Press.

Clark, C., Emmanouil, N., Page, J. \& Pelizzo, A. (2019). Can you hear the rivers sing? Legal personhood, ontology and the nitty-gritty of governance. Ecology Law Quarterly, 45, 787-844. doi: 10.15779/Z388S4JP7M. 
Miranda Forsyth, Deborah Cleland, Felicity Tepper, Deborah Hollingworth, Milena Soares, Alistair Nairn and Cathy Wilkinson

Cleland, D. \& Ocaya, R. (2018). Rehearsing inclusive participation through fishery stakeholder workshops in the Philippines. Conservation and Society, 16(3), 351-362. doi: 10.4103/cs.cs_17_50.

Cooke, B. \& Kothari, U. (2001). Participation: the new tyranny? London: Zed Books.

Cooney, J. (2017). Reflections on the 20th anniversary of the term 'social licence'. Journal of Energy \& Natural Resources Law, 35(2), 197-200. doi: 10.1080/02646811.2016.1269472.

Cullinan, C. (2017). Wild law: a manifesto for Earth justice. White River Junction: Chelsea Green Pub.

Davies, P.A. (2014). Green crime and victimization: tensions between social and environmental justice. Theoretical Criminology, 18(3), 300-316. doi: 10.1177/1362480614522286.

Demuijnck, G. \& Fasterling, B. (2016). The social license to operate. Journal of Business Ethics, 136, 675-685. doi: 10.1007/s10551-015-2976-7.

Dore, A. (2019). Fighting for our rhinos. Endangered Wildlife Trust. Retrieved from www.ewt.org.za/sp-sept-2019-fighting-for-our-rhinos/ (last accessed 04 August 2020).

Dovers, S. (1998). Community involvement in environmental management: thoughts for emergency management. Australian Journal of Emergency Management, 13(2), 6-11.

Duncan, E., Graham, R. \& McManus, P. (2018). 'No one has even seen... smelt... or sensed a social licence': Animal geographies and social licence to operate. Geoforum, 96, 318-327. doi: 10.1016/j.geoforum.2018.08.020.

Edwards, P., Fleming, A., Lacey, J., Lester, L., Pinkard, E., Ruckstuhl, K., Bezuidenhout, C., Payn, T., Bayne, K. \& Williams, T. (2019). Trust, engagement, information and social licence - insights from New Zealand. Environmental Research Letters, 14(2), 1-9. doi: 10.1088/1748-9326/aaf33c.

Froestad, J. \& Shearing, C. (2007). Beyond restorative justice - Zwelethemba, a future focused model of local capacity conflict resolution. In R. Mackay, M. Bošnjak, J. Deklerck, C. Pelikan, B. van Stokkom \& M. Wright (eds.), Images of restorative justice theory (pp. 16-34). Frankfurt am Main: Verlag für Polizeiwissenschaft.

Gavrielides, T. (2008). Restorative justice - the perplexing concept: conceptual fault-lines and power battles within the restorative justice movement. Criminology and Criminal Justice, 8(2), 165-183. doi: 10.1177/1748895808088993.

Golub, A., Mahoney, M. \& Harlow, J. (2013). Sustainability and intergenerational equity: do past injustices matter? Sustainability Science, 8, 269-277. doi: 10.1007/ s11625-013-0201-0.

Goyes, D.R., Sollund, R. \& South, N. (2019). Towards global green criminological dialogues: voices from the Americas and Europe. International Journal for Crime, Justice and Social Democracy, 8(3), 1-5. doi: 10.5204/ijcjsd.v8i3.1240.

Gunningham, N., Kagan, R.A. \& Thornton, D. (2004). Social license and environmental protection: why businesses go beyond compliance. Law \& Soc. Inquiry, 29(2), 307-341. doi: 10.1111/j.1747-4469.2004.tb00338.x.

Gunningham, N. \& Holley, C. (2016). Next-generation environmental regulation: law, regulation, and governance. Annual Review of Law and Social Science, 2, 273-293. doi: 10.1146/annurev-lawsocsci-110615-084651.

Hamilton, M. \& Howard, T. (2020). Restorative justice in the aftermath of environmental offending: theory and practice. Retrieved from https://njca.com.au/wp-content/ uploads/2020/03/Restorative-Justice-in-the-Aftermath-of-Environmental-OffendingHamilton-M-and-Howard-T.pdf (last accessed 04 August 2020). 
Hampton, J.O. \& Teh-White, K. (2019). Animal welfare, social license, and wildlife use industries. The Journal of Wildlife Management, 83(1), 12-21. doi: 10.1002/jwmg. 21571.

Holifield, R., Chakraborty, J. \& Walker, G. (2017). Introduction: the worlds of environmental justice. In R. Holifield, J. Chakraborty \& G. Walker (eds.), The Routledge handbook of environmental justice (pp. 1-11). London: Routledge.

Holley, C. (2009). Aging gracefully? Examining the conditions for sustaining successful collaboration in environmental law and governance. Environmental and Planning Law Journal, 26, 457-485.

Jessup, B. (2017). Trajectories of environmental justice: from histories to future and the Victorian environmental justice agenda. Victoria University Law and Justice Journal, 7, 48-65. doi: 10.15209/vulj.v7i1.1043.

Koppell, J.G.S. (2005). Pathologies of accountability: ICANN and the challenge of 'multiple accountabilities disorder'. Public Administration Review, 65(1), 94-108. doi: 10.1111/j. 1540-6210.2005.00434.x.

Lester, L. (2016). Media and social licence: on being publicly useful in the Tasmanian forests conflict. Forestry, 89, 542-551. doi: 10.1093/forestry/cpw015.

Llewellyn, J. (2019). Responding restoratively to student misconduct and professional regulation - the case of Dalhousie dentistry. In G. Burford, J. Braithwaite \& V. Braithwaite (eds.), Restorative and responsive human services (pp. 127-142). London: Routledge.

Lowe, I. (2014).Wild law embodies values for a sustainable future. In M. Maloney \& P. Burdon (eds.), Wild law - in practice (pp. 3-16). London: Routledge.

Lynch, M.J. \& Stretesky, P.B. (2011). Similarities between green criminology and green science: toward a typology of green criminology. International Journal of Comparative and Applied Criminal Justice, 35(4), 293-306. doi: 10.1080/01924036.2011.625233.

Lukasiewicz, A. (2016). Environment and justice: defining the field. In A. Lukasiewicz, S. Dovers, L. Robin, J. McKay, S. Schilizzi \& S. Graham (eds.), Natural resources and environmental justice: Australian perspectives (pp. 1-11). Clayton South: CSIRO Publishing.

Moore, D. (2019). Private communication at Restorative Justice Symposium, 24 October 2019, Melbourne.

Moore, P., Greiber, T. \& Baig, S. (2010). Strengthening voices for better choices: forest governance and law enforcement: findings from the field. IUCN. Retrieved from https:// portals.iucn.org/library/node/12712 (last accessed 04 August 2020).

Nurse, A. (2015). An introduction to green criminological theories. In A. Nurse (ed.), An introduction to green criminology and environmental justice (pp. 19-36). London: SAGE Publications.

Nygren, A. (2004). Contested lands and incompatible images: the political ecology of struggles over resources in Nicaragua's Indio-Maíz Reserve. Society and Natural Resources, 17(3), 189-205. doi: 10.1080/08941920490270221.

Pemberton, A. \& Aarten, P.G.M. (2018). Narrative in the study of victimological processes in terrorism and political violence: an initial exploration. Studies in Conflict \& Terrorism, 41(7), 541-556. doi: 10.1080/1057610X.2017.1311110.

Polk, M. (2014). Achieving the promise of transdisciplinarity: a critical exploration of the relationship between transdisciplinary research and societal problem solving. Sustainability Science, 9, 439-451. doi: 10.1007/s11625-014-0247-7.

Richardson, B.J. (2015). Reclaiming nature: eco-restoration of liminal spaces. Australian Journal of Environmental Law, 2, 1-23. 
Rossner, M. (2013). Just emotions: rituals of restorative justice. Oxford: Oxford University Press.

SPC. (2020). White paper on China's environmental resource trial. Retrieved from the Supreme People's Court (SPC) of the People's Republic of China: www.court.gov.cn/ zixun-xiangqing-228341.html (last accessed 04 August 2020). [In Chinese]

Smith, C. \& Freyd, J. (2014). Institutional betrayal. American Psychological Association, 69(6), 575-587. doi: 10.1037/a0037564.

Steinebach, Y. (2019). Instrument choice, implementation structures, and the effectiveness of environmental policies: a cross-national analysis. Regulation \& Governance, 30 December 2019, 1-18. doi: 10.1111/rego.12297.

Stretesky, P., Lynch, M.J. \& Long, M.A. (2014). The treadmill of crime: political economy and green criminology. London: Routledge.

Taylor, D.E. (2000). The rise of the environmental justice paradigm: injustice framing and the social construction of environmental discourses. American Behavioral Scientist, 43(4), 508-580. doi: 10.1177/0002764200043004003.

White, R. (2017). Reparative justice, environmental crime and penalties for the powerful. Crime, Law and Social Change, 67(2), 117-132. doi: 10.1007/s10611-016-9635-5.

White, R. (2018). Ecocentrism and criminal justice. Theoretical Criminology, 22(3), 342-362. doi: $10.1177 / 1362480618787178$.

Wijdekop, F. (2019a). Reconnecting with the living earth through restorative justice. Retrieved from www.kosmosjournal.org/news/reconnecting-with-the-living-earth-throughrestorative-justice/ (last accessed 04 August 2020).

Wijdekop, F. (2019b). Restorative justice responses to environmental harm. Eigen Publicaties. Retrieved from www.restorativejustice.nl/user/file/rapportiucnnl.pdf (last accessed 04 August 2020).

Zehr, H. (2014). The little book of restorative justice. New York: Good Books. 